\title{
Microstructural evaluation by confocal and electron microscopy in thrombi developed in central venous catheters
}

\author{
Avaliação microestrutural por microscopia confocal e eletrônica em \\ trombos desenvolvidos em cateteres venosos centrais \\ Evaluación microestructural por microscopia confocal y electrónica \\ en trombos desarrollados en catéteres venosos centrales
}

\author{
Thabata Coaglio Lucas ${ }^{1}$, Eliata Ester da Silva ${ }^{1}$, Danilo Olzon Dionysio Souza ${ }^{2}$, Amanda Rodrigues dos Santos ${ }^{1}$, Maristela $^{2}$ \\ Oliveira Lara ${ }^{1}$
}

How to cite this article:

Lucas TC, Silva EE, Souza DOD, Santos AR, Lara MO. Microstructural evaluation by confocal and electron microscopy in thrombi developed in central venous catheters. Rev Esc Enferm USP. 2017;51:e03247. DOI: http://dx.doi.org/10.1590/S1980-220X2016038103247

${ }^{1}$ Universidade Federal dos Vales do

Jequitinhonha e Mucuri, Departamento de Enfermagem, Diamantina, MG, Brazil.

${ }^{2}$ Universidade Federal dos Vales do Jequitinhonha e Mucuri, Departamento do Instituto de Ciência e Tecnologia, Diamantina, MG, Brazil.

\begin{abstract}
Objective: Evaluating thrombi microstructure developed in central venous catheters using confocal and electron microscopy. Method: An experimental, descriptive study carrying out a microstructural evaluation of venous thrombi developed in central venous catheters using Scanning Electron Microscopy and Confocal Laser Scanning Microscopy. Results: A total of 78 venous catheters were collected over a period of three months. Different fibrin structures were distinguished: fibrin plates, fibrin network, and fibrin fibers. It was observed that the thrombus had thick fibrin plates adhered to the catheter wall openings in both a catheter with three days of permanence as well as in a catheter with 20 days of insertion in the patient. However, a greater amount of erythrocytes and fibrin fibers were found in the central region of the thrombus. Conclusion: This study contributes to improving health care and can have a positive impact on clinical practice, as easy adherence of platelets and fibrins to the catheter wall demonstrated in this study makes it possible to adopt thrombus prevention strategies such as therapy discontinuation for an extended period, blood reflux by a catheter, slow infusion rate and hypercoagulo pathyclinical conditions.
\end{abstract}

DESCRIPTORS

Catheters; Central Venous Catheters; Microscopy; Fibrin; Nursing Care.
Corresponding author:

Thabata Coaglio Lucas

Rua Valmira Pires, 140, Apto. 204 - Bairro Fátima

CEP 39100-000 - Diamantina, MG, Brazil

thabata.coaglio@ufvjm.edu.br
Received: 10/05/2016

Approved: 04/11/2017 


\section{INTRODUCTION}

Insertion of central venous catheters (CVCs) is frequent in the Intensive Care Units for the purposes of hemodynamic monitoring, maintaining an infusion route of solutions, medications, parenteral nutrition, hemodialysis, and blood sample collection, among others. Central venous catheters $(\mathrm{CVCs})$ are radiopaque, and made of silicone, polyurethane or teflon. They may have one to three lumens arranged in parallel at the proximal end, and generally have lateral orifices at their distal end ${ }^{(1-3)}$. The openings may induce fibrin formation and subsequent thrombus development. Fibrin sheaths are composed of fibrinogen, albumin, lipoproteins, and coagulation factors that begin within 24 hours after catheter insertion ${ }^{(1-4)}$. Fibrin is the first structural protein to form in thrombus composition and it may lead to catheter occlusion, extravasation of infused fluid, exchanging the catheter and loss of secondary access to thrombosis ${ }^{(5)}$. Catheter malfunction often occurs due to the formation of thrombi, and has been the primary indication for its removal ${ }^{(5-7)}$. Initial forming and maturing of the different thrombotic tissue components may lead to occlusion of the $\mathrm{CVC}$ lateral openings, mainly due to different conformations of the fibrin inside the opening and its adsorption to polymeric materials. Fibrin deposition on the catheter causes the surface to encapsulate, forming a sheath at the distal tip of the catheter ${ }^{(4-5)}$. The process of protein adsorption to the polymer may become irreversible, and tissue dissolution becomes ineffective even by introducing fibrinolytic agents due to strong covalent bonds between plasma proteins and the catheter wall ${ }^{(2-3)}$. The activation of a coagulation cascade increases the tendency for thrombus formation, which is an important cause of complications in patients using a venous catheter, which can not only lead to thrombosis near the vascular access, but also to emboli formation, deep venous thrombosis and the possible development of cardiac ischemia ${ }^{(8-14)}$. Analysis by Confocal Laser Scanning Microscopy is an optical technique based on fluorescence induction by an absorption photon, which demonstrates high potential in characterizing biological samples in the hydrated state without the need to section them ${ }^{(14)}$. It has recently been applied to studies of in vivo thrombosis formation and aided thrombolytic treatment in cannulated rats $^{(14-16)}$. Considering the three-dimensional microscopic architecture of a thrombus, Scanning Electron Microscopy (SEM) is one of the elective techniques for morphological characterization ${ }^{(13)}$. However, despite having high potential, SEM only provides information on superficial thrombus layers and their structural analysis ${ }^{(2-3)}$. Integrating SEM and Confocal Laser Scanning Microscopy are promising for investigating thrombi in human samples, thus enabling better care performance in clinical practice and in the maintenance of CVCs, as they are evidence-based practices that respond to issues that arise daily. It is imperative to rethink the practice, and know that it is possible to reduce patient complications. The present research aims to contribute to the definition of new research methods and protocols for evaluating CVCs. It also contributes to implementing intervention strategies aimed at improving the quality of care in health services. Furthermore, as justification for this study, we point out that despite the existence of several factors that contribute to thrombi formation, the structure of this tissue within the CVC has not yet been fully clarified in the literature. Pilot studies aiming at a better understanding of their morphology are important for identifying new risk factors for future research in population studies. Thus, the present study can provide indicators to reduce potential adverse events that could occur in patients using CVCs, which still represent a challenge for the health services. The objective of this study was to evaluate the microstructure of thrombi developed in central venous catheters using confo$\mathrm{cal}$ and electron microscopy.

\section{METHOD}

This is a descriptive experimental study comparing the microstructure of thrombi developed in patients after insertion of CVCs. Catheters were collected from the Intensive Care Unit of a philanthropic hospital in the interior of Minas Gerais from June 1 to August 31, 2016. Inclusion criteria were: Patients aged 18 or older; who had received indication for central venous catheter; were using CVC, regardless of the underlying chronic disease and therapeutics used; and who agreed to participate in the study. Thrombi located in catheters inserted into the right and left internal jugular vein and right and left subclavian vein were analyzed. Those inserted into the femoral vein were excluded from the study. Femoral veins were excluded as an anatomical site of catheter insertion due to the density of the resident microbiota of the skin, representing a risk factor for infection.

The study was carried out at the Integrated Research and Post-graduation Center of the Universidade Federal dos Vales do Jequitinhonha e Mucuri (UFVJM).A form containing the following information was filled out for collecting the CVCs: Use of anticoagulant in case of malfunction due to flow problem; whether the catheter was tunneled or non-tunneled, insertion site, site and date of CVC insertion, date and cause for catheter removal. Regarding the cause for removal, the following criteria were also established in the form: flow problem, poor positioning, CVC-related infection, catheter rupture, and those removed according to recommended by the institution, meaning without complications.

The present study respected the ethical aspects of Resolution 466 of the National Health Council of December 12, 2012. The study was approved by the Research Ethics Committee of the UFVJM under opinion number 1.581.856. A Free and Informed Consent Form was given to each patient for their knowledge and authorization to use their thrombotic tissue after CVC removal. All CVCs were washed with $0.9 \%$ saline solution and fixed with $4 \%$ buffered formaldehyde immediately after being removed from the patient. Photographic documentation was performed in $10 \mathrm{~cm}$ catheter distal section with a scalpel after at least 48 hours of fixation. Segments of approximately $5 \mathrm{~mm}$ in length were isolated and sectioned from 
the catheter using a scalpel, as shown in Figure 1. An XL30 ESEM FEG FEI-Philips Scanning Electron Microscope (The Netherlands) was used for SEM. The samples were placed on a metal support and then the gold covering was made (Sputter Coater K500X, Emitech.) with $15 \mathrm{~mA}$ for
2.5 minutes. High definition micrographs were obtained with a magnification of 500 to 4,000x. Figure 1 presents photographic documentation of the fibrin-rich thrombus inside the CVC openings after a permanence period of 5, 15 , and 20 days.

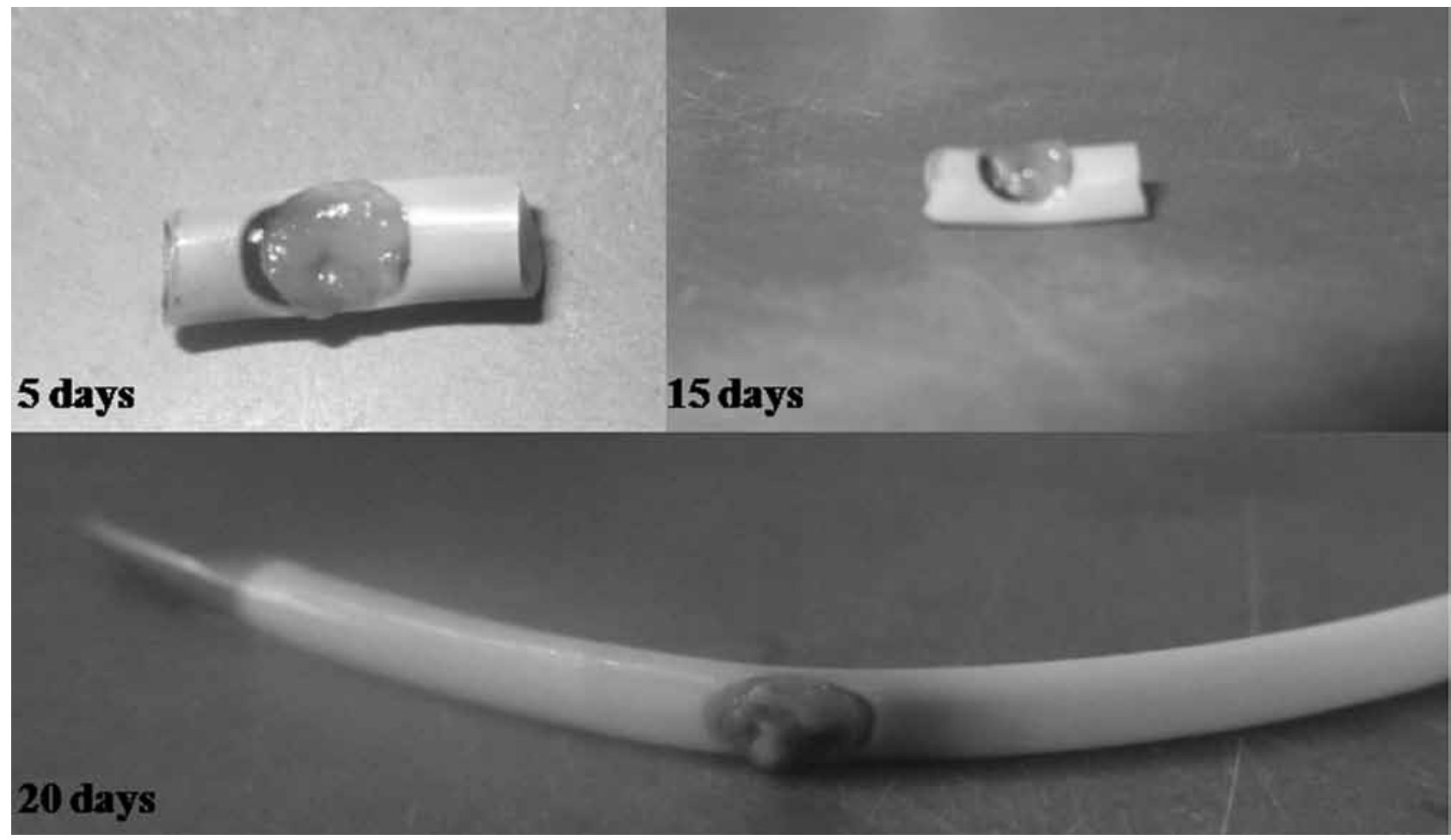

Figure 1 - Photographic documentation of the fibrin-rich thrombus inside the CVCs openings. Source: Elaborated by the authors.

Regarding catheters observed in the Confocal Laser Scanning Microscope (LSM 700; Carl Zeiss, Oberkochen, Germany), the samples were cut into two halves through two cross-sections in the center of the segment using a scalpel. This section was made for better analysis of the hydrated sample under the microscope. Excitation wavelength was $488 \mathrm{~nm}$. The samples were washed by immersion for 2 minutes in deionized water, fixed with fluorescent dye by immersion in $1 \mathrm{mM}$ Rhodamine 6G solution (Sigma-Aldrich $n^{\circ}$ 83697, St. Louis, MO, USA) in deionized water for 20 minutes in a dark room. The images were processed in the Image $\mathrm{J}^{\circledast}$ program (NIH, USA), converted to TIFF to standardize false color images and qualitatively evaluate the presence of fibrin, erythrocytes, leukocytes and platelets.

\section{RESULTS}

A total of $78 \mathrm{CVCs}$ were collected over a period of 3 months in the Intensive Care Unit of the study hospital. All catheters had flow malfunction during hospitalization, repaired by administering anticoagulant within the catheter lumen. We emphasize that the collected catheters were routinely washed with $0.9 \%$ saline solution administered by flushing to prevent formation of clots and thrombi. All 78 collected catheters were non-tunneled; $38(48.72 \%)$ were inserted in the right internal jugular (vein), six (7.69\%) in the left internal jugular and $34(43.59 \%)$ in the right subclavian (vein). Sixty-seven $(85.80 \%)$ of the evaluated catheters presented venous thrombus inside the openings, as shown in Figure 1. Fifty-four (80.60\%) of the CVCs that presented thrombus had been removed due to flow problems. The others had been removed according to the hospital's recommendation, meaning they were not removed due to CVC infection, flow problems, catheter breakage, or poor positioning. Regarding thrombus microstructure, the following compositions were identified: a) Fibrin plate: thick and dense fibrin network; b) Fibrin network: fibrin mesh with coarse and fine fibers arranged intertwined and tangled; c) Fibrin fibers: fibrin network of fibers with a single fiber strand; d) Platelets: cells in the form of irregular discoid with about $2 \mu \mathrm{m}$ in diameter appearing as aggregated or adhered to fibrin fibers; e) Erythrocytes: biconcave disc-shaped cells of about $7 \mu \mathrm{m}$ in diameter; f) Leukocytes: spherical structures with irregular surface of about 6 to 8 $\mu \mathrm{m}$ in diameter. Figure 2 (a) shows a venous thrombus rich in erythrocytes. The arrow points to an erythrocyte. Figure 2 (b) shows a fibrin network covering a fibrin plaque. The arrow points to the fibrin strands forming the network. Figure 2 (c) shows a fibrin fiber, while Figure 2 (d) shows the fibrin plate and the platelets adhered to it. The arrow points to the platelet. 

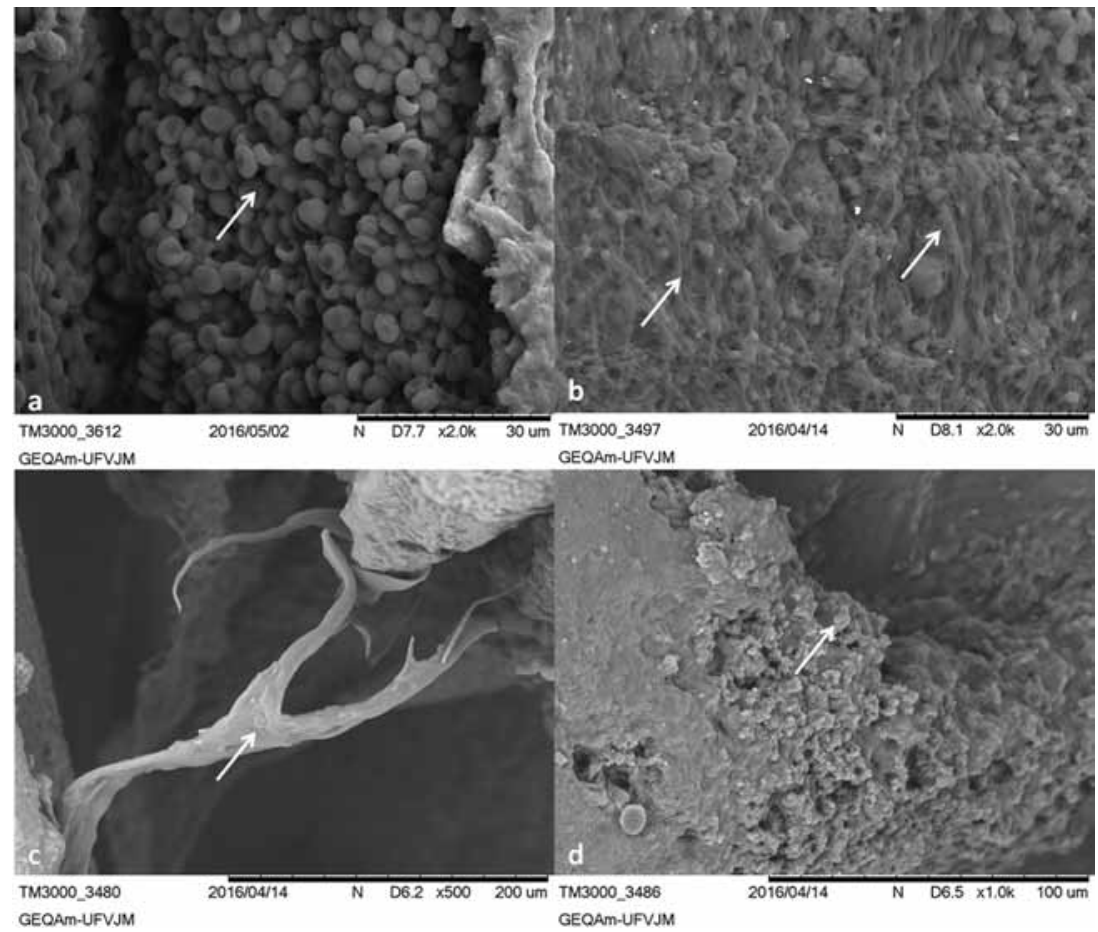

Figure 2 - Distribution of the microstructures of the venous thrombi identified in SEM. Original magnification: 500x, 1,000x and 2,000x. Source: Elaborated by the authors.

It is worth pointing out that of the 67 catheters that contained thrombus in their interior, 13 (19.41\%) remained inserted in the patient for 3 days, 19 (28.35\%) remained for 5 days, $15(22.38 \%)$ remained for 8 days, 10 (14.92\%) remained for 10 days, 7 (10.44\%) remained for 15 days, and 3 (4.41\%) catheters remained for 20 days. Thus, the mean permanence time of the analyzed catheters was 7 days. Figure 3 (a) shows the catheter opening with a small tissue adhered to the wall. Figure 3 (c) is an enlargement of the selected site on the thrombus. Leukocytes are present in this region. Figure 3 (b) shows a fibrin plate. Figure 3 (d) shows erythrocytes adhered to fibrin fibers. Arrows point to the fiber and the erythrocyte.

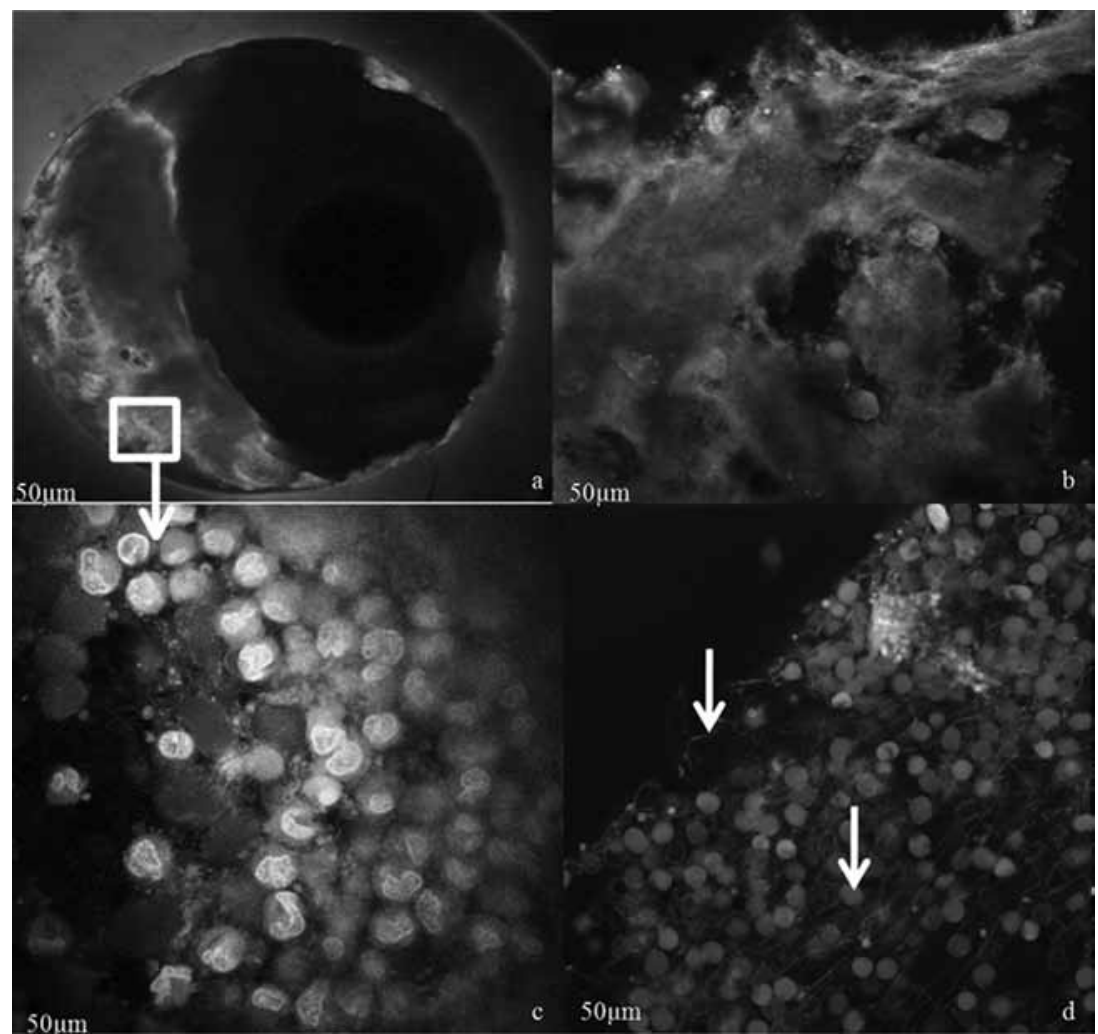

Figure 3 - Distribution of images of the thrombus obtained by Confocal Laser Scanning Microscopy. Source: Elaborated by the authors 
Figure 4 shows thrombi within the CVCs that remained in the patient for 3,10 and 15 days. An enlargement of the fibrin plate in the thrombus that was inside the catheter that remained for 15 days may be observed.
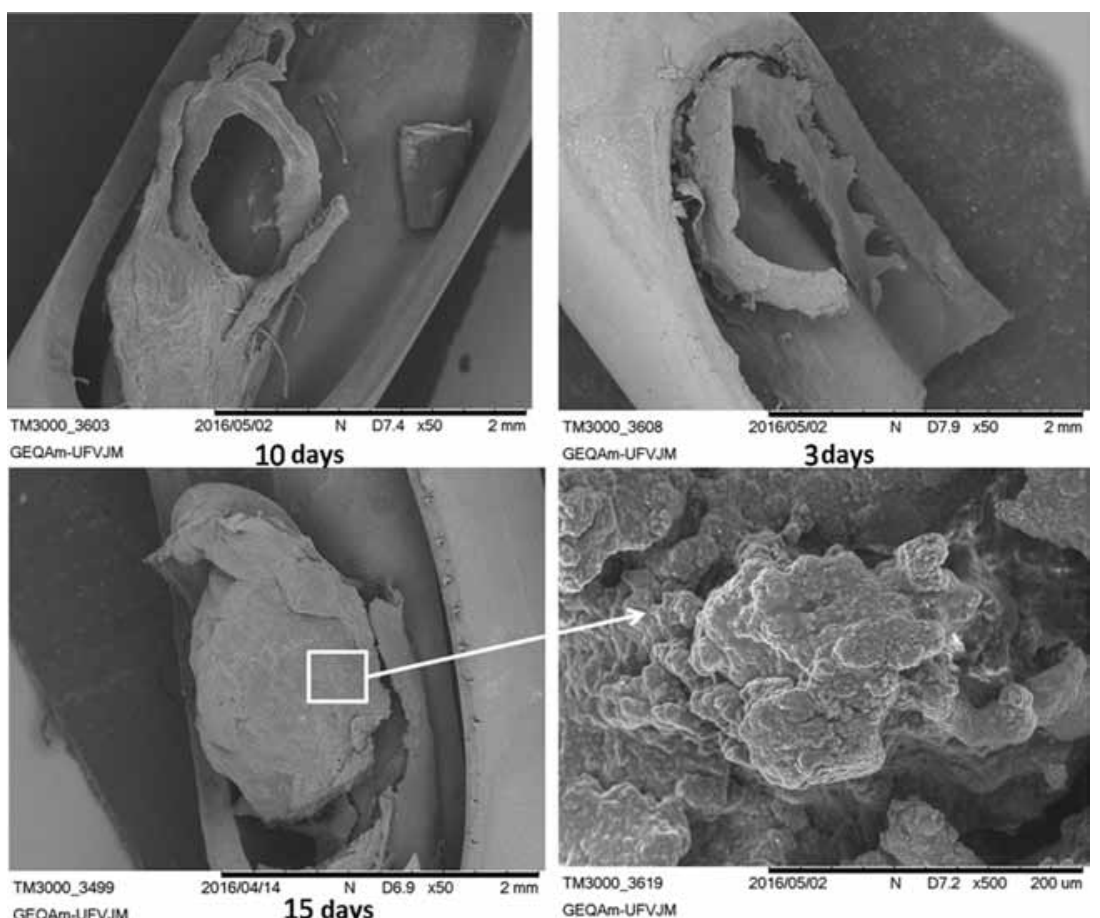

Figure 4 - Distribution of the venous thrombi microstructures inside the CVCs opening by SEM. Original magnification: 500x, 1,000x and 2,000x. Source: Elaborated by the authors.

It is observed in Figure 4 that a large amount of fibrin plaque was noticed regardless of the catheter's permanence time. There was no thrombus evolution in the course of thcatheter's permanence time in the patient.

Figure 5 shows photographic documentation of thrombus within the CVC opening and Confocal Laser Scanning Microscopy images. The central region of the thrombus presented large numbers of erythrocytes and the fibrin plates were adhered to the side wall of the CVC opening.

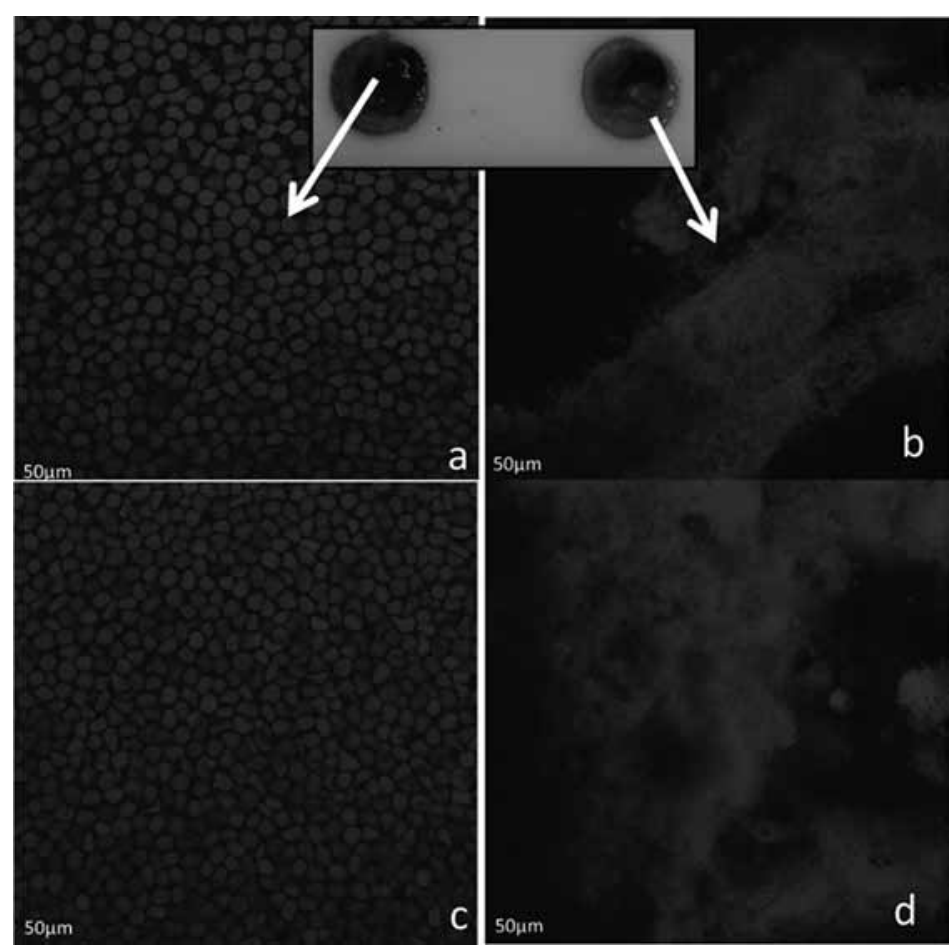

Figure 5 - Photographic documentation of the thrombus inside the CVC opening and Confocal Laser Scanning Microscopy images corresponding to the thrombotic tissue content. Source: Elaborated by the authors. 


\section{DISCUSSION}

Unlike thrombi with homogeneous structure composed predominantly of erythrocytes and sparse regions of fibrin and platelets described from in vitro or laboratory animal studies $^{(4,15-16)}$, the thrombus evaluated in the present study had a heterogeneous structure. Large amounts of fibrin layers and platelets were observed near the vessel wall, and fibrin layers with erythrocytes were present in higher quantity in the center of the thrombus (Figures 4 and 5). The impact on clinical care practice is that in the event of an obstruction, lumen irrigation with anticoagulant (for example) may only dissolve erythrocytes. Dissolution of the thick fibrin plaque adhered to the vessel wall may not occur since the collagen and elastin fibers form strong covalent bonds with the catheter wall ${ }^{(15-16)}$. This contributes to rapid thrombus evolution in a few days, since not all thrombotic tissue was removed. In addition, different types of polymers influence the biological response to the surface, including protein adsorption and the adsorbed fibrinogen activity ${ }^{(4-5,8)}$. The interaction between proteins and polymer will depend on the type of material, the functional groups and the hydrophilic and hydrophobic domains with appropriate sizes that correspond to the proteins' surface ${ }^{(5,8,17)}$. It is known that hydrophobic surfaces (like most polymers) maintain strong bonds with adsorbed proteins ${ }^{(4-5,12,15)}$. Catheters stimulate fibrinogenesis, and leads to the formation of numerous thick fibrin chains that can result in a fibrous capsule around the entire distal region of the catheter ${ }^{(1,4)}$. Such an arrangement of thick fibers may lead to adverse events in patients, such as pulmonary embolism, post-thrombotic syndrome and persistent vessel impairment ${ }^{(11,14)}$. The present study evaluated a thrombus with venous and non-arterial characteristics. Arterial thrombi have high concentrations of platelets and low concentrations of red blood cells, referred to as a white thrombus ${ }^{(10-12)}$. Venous thrombi usually mainly consist of fibrins and red blood cells, with varying amounts of platelets and white blood cells. Venous thrombi are rich in fibrins and covered by red blood cells, and are therefore referred to as red thrombus ${ }^{(10-12)}$. A case study using SEM observed a thrombus from a deep vein thrombosis taken from a patient ${ }^{(4)}$, and concluded that due to the high pulmonary flow speed, the thrombi in the pulmonary arteries presented a greater quantity of fibrin and a smaller number of erythrocytes in comparison to leukocytes. The high number of white blood cells may have occurred because of a recent in vivo modulation or degradation activity of the thrombus. Different from this study, erythrocytes within venous thrombus were predominant in all samples when compared to leukocytes.

The images obtained from Confocal Laser Scanning Microscopy showed that the greater the depth of the thrombotic tissue evaluated, the lower the fibrin concentration and the greater quantity of red cells not interconnected to the fibrin network. These results were also found by a study evaluating the thrombus present in central venous catheters by Two-photon laser scanning microscopy ${ }^{(2)}$. This type of microscopy reaches a greater tissue depth when compared to Confocal Laser Scanning Microscopy, and the greater the tissue depth evaluated, the greater the red blood cell and white blood cell concentration, and the smaller the amount of fibrin interconnected to the cells ${ }^{(2)}$. In another study, a venous thrombus was observed by Two Photon Laser Scanning Microscopy in which the fibrin plate was surrounded by white blood cells close to the inner wall of the catheter opening ${ }^{(3)}$. This observation was also found in the present study while evaluating a thrombus using Confocal Laser Scanning Microscopy after 5 days of catheter permanence in the patient (Figures $3 \mathrm{a}$ and $3 \mathrm{c}$ ). The white blood cells surrounding the fibrin plate surface may be associated with the biocompatibility of the material, mainly in regions of stagnation and blood flow recirculation which are regions in which the blood circulates near the catheter and which generates inflammatory reactions in the vessels ${ }^{(10,12)}$. The inflammatory process that the catheter triggers in the bloodstream in these regions is more accelerated because the monocytes and neutrophils are retained in the low flow velocity regions, and as they pass along the catheter they adhere to the polymer wall, thus triggering an initial stimulus for thrombus development ${ }^{(4,12)}$.

Catheter contact with the blood and the subsequent adsorption of plasma proteins on the surface of the material leads to a network consisting of fibrin aggregates and platelets enclosing the interior of the entire catheter wall in less than 24 hours $^{(8-9)}$. Fibrin adhered to the polymer surface activates platelet aggregation, extrinsic and intrinsic coagulation, polymerization of fibrin monomers from fibrinogen (coagulation factor present in plasma) and crosslinking of the fibers to form a dense network of fibrin ${ }^{(8-9)}$. The present study found that the amount of total fibrin was the main thrombus component, and that the remainder of its surface composition primarily consisted of red blood cells trapped in fibrin networks. These results are in accordance with a morphological study performed with intracoronary thrombus obtained by thrombo aspiration after myocardial infarction ${ }^{(13)}$. In that study, fibrin was the main component of the thrombus, accounting for more than $60 \%$ of the tissue composition after 6 hours of vessel obstruction ${ }^{(13)}$. Likewise according to a morphological study of thrombi, fibrin was also found as the largest amount in tissue constitution when evaluating thrombi present in central venous hemodialysis catheters ${ }^{(4)}$. According to another study, a venous thrombus removed from a patient observed in SEM showed sparse and constitutionally tapered fibrin networks, characteristic of recent thrombus ${ }^{(5,7,17)}$. However, in the present study, the small thrombus that formed in the catheter lumen opening matured in a short time (it had thick fibrin plaques in 3 days), which increases the risk of detachment and pulmonary embolism. The morphology and composition of a thrombus undergoes modifications from the initial phase until complete catheter obstruction ${ }^{(17)}$. SEM analysis allowed for distinguishing differences between fibrin structures. The fibrins contained in the venous thrombus were classified as: Fibrin plaque, fibrin network and fibrin fibers (Figure 2). It is interesting to note that fibrin fibers were not found in all the thrombi contained within the interior of the 
catheter openings. Thrombi with sparsely distributed fibrin fibers develop rapidly to form the fibrin network. The fibers become dense and aggregated with platelets in the initial phase of the thrombus, favoring coagulation activation and the continuous formation of a fibrin network.

The resulting thrombus is composed of erythrocytes, platelets and inflammatory cells covered by a fibrin network (Figure 3d). In the coagulation process, thrombin converts fibrinogen to fibrin by fibrinopeptide cleavage and the formation of a structure called protofibril ${ }^{(16-17)}$. When the phylopod grows, it forms a long structure that aggregates laterally to form fibrin fibers (Figure 4b). However, it sometimes diverges, producing separate branches of fibers ${ }^{(16-17)}$. And, according to chemical and physical conditions, lateral aggregation tends to produce thrombus made of thick fibers with few thin branches of fibers (Figure $4 b$ ). On the other hand, if lateral aggregation is inhibited, the thrombus will contain thin, non-dense fibers and many fibrin fiber branches. This process can be compared to the present study where lateral aggregation occurs with fibrin plaque accumulation at the catheter border, and the fibrin network and fibers at the central region of the thrombus (Figure 5). Fibrin plaque represented the most common structure in the thrombus and was densely structured, even at 3 days of central venous catheter permanence in the patient's vein (Figure 4). This confirms that the fully structured thrombus may develop in the catheter opening and lumen within a short time after catheter insertion. A thrombus that forms inside the catheter opening and continues to grow can lead to its complete obstruction ${ }^{(6,9,16)}$. Fibrin usually develops on contact between the end of the catheter and the vessel wall within 24 hours after catheter insertion ${ }^{(5,15-17)}$, and it could eventually completely block the catheter over a period of 3 to 5 days, as seen in Figure 4. A thrombus that initially forms inside the catheter opening may grow, causing vein obstruction and resulting in organ loss, with life-threatening potential. A prevalence study conducted with patients using central venous catheters showed that $23(62 \%)$ of the 37 evaluated patients developed thrombosis ${ }^{(6)}$. Literature also reports an incidence of post-thrombotic syndrome of up to $80 \%$ of cases $^{(6)}$. It is important to note that the combination of SEM and Confocal Laser Scanning Microscopy has been useful to highlight some important considerations regarding sample preparation. Although fixation preserves cell membrane and fibrin structure integrity, the dehydration and drying process required by SEM can induce significant thrombus shrinkage reaching $10 \%$ to $40 \%$ of the total volume. Low magnification images were therefore compared to photographic documentation acquired in the hydrated state to correctly identify the original thrombus surface exposed to the bloodstream inside the vein. In comparing paired samples by SEM and Confocal Laser Scanning Microscopy, it is possible to note that microstructural architectures of fibrin and cells were preserved. In this study, this fact suggested a new way of understanding fibrin stability, the architecture and mechanisms of interaction between fibrin, platelets, red blood cells and white blood cells within the thrombus. This may help understanding thrombus formation over time and fibrin arrangement within the thrombus in deeper layers of the catheter opening, which would represent a breakthrough for improving health care and nursing practices.

Despite the increased use of central venous catheters, a lack of understanding remains regarding the risk of thrombus development within CVCs. An experimental study observed that blood platelet count of patients hospitalized in an Intensive Care Unit increased with the central venous catheter's permanence time ${ }^{(2)}$. This finding contributes to the fact that nurses and the entire multiprofessional team are aware of problems related to CVC malfunction due to flow problems. The microstructure and fibrin conformation evaluation conducted in this study can also be used to verify the effectiveness of the lock-therapy solution, and the treatment effectiveness to restore blood flow in blocked CVCs. Many questions about the effectiveness of the lock-therapy solution for patients with catheter-related thrombi are still unresolved ${ }^{(12-14)}$. The influence of the lock-therapy solution on the amount and structure of the fibrin formed inside the catheter could be evaluated through applying the techniques reported in this study, including prospective studies.

\section{CONCLUSION}

Considering the main results found in this study, we conclude that: a) thrombus found within central venous catheters presented a greater composition of fibrins, followed by erythrocytes and a variable amount of platelets and white blood cells. Fibrin was discriminated into fibrin plaque, fibrin network and fibrin fibers inside the venous thrombus found in the CVC for better analysis of its conformation and architecture; $b$ ) regardless of catheter permanence time, fibrins adhere to the side walls of the catheter openings. The adsorption process is permanent, and therefore fibrinolytic and anticoagulants agents will probably only dissolve in the central region of rich red blood cell thrombus. The region rich in fibrin plaques adhered to the catheter wall will probably not be destroyed. Future hemocompatibility studies using a polymer material in order to lower adhesion of blood proteins and lower platelet aggregation to the polymers should be performed. Strategies for preventing and treating catheter occlusion are suggested through developing new anticoagulant, thrombolytic and fibrinolytic agents that prevent fibrin formation. It would be interesting if the treatment prevented fibrin from forming covalent bonds with the catheter wall and did not remain adhered. Thus, the destruction of the thrombus would be complete and it would be a way of hindering development of a new thrombus in the same place. Future research could focus on strategies for preventing, diagnosing and treating catheter occlusion.

The methodological techniques reported in this study provide the multiprofessional team with up-to-date information on thrombi formation in CVCs. Such information makes it possible to recognize the risks and complications arising from the use of this device, and as a consequence may improve health professional interventions on how to treat them. SEM and Confocal Laser Scanning Microscope tissue evaluations can be adopted at health institutions or through partnerships with educational institutions, and 
despite the operational cost they would be economically viable due to a decrease in institutional costs from the occurrence of adverse events.

This study contributes to improve health care and can have a positive impact on clinical practice, since the facilitated adhesion of platelets and fibrins to the catheter wall demonstrated in this study enables adopting thrombus prevention strategies such as therapy discontinuation for a prolonged period, blood reflux by the catheter, slowing the infusion rate and the clinical condition of hypercoagulopathy.

\section{RESUMO}

Objetivo: Avaliar a microestrutura por microscopia confocal e eletrônica em trombos desenvolvidos em cateteres venosos centrais. Método: Pesquisa experimental, descritiva, em que foi feita uma avaliação microestrutural de trombos venosos desenvolvidos em cateteres venosos centrais por Microscopia Eletrônica de Varredura e Microscopia Confocal de Varredura a Laser. Resultados: Foram coletados 78 cateteres venosos centrais num período de três meses. Distinguiram-se diferentes estruturas de fibrina: a placa de fibrina, a rede de fibrina e as fibras de fibrina. Observou-se que tanto em um cateter com três dias de permanência quanto em um cateter com 20 dias inserido no paciente o trombo apresentou placas de fibrina espessas aderidas às paredes dos orifícios dos cateteres. Na região central do trombo, no entanto, observou-se maior quantidade de eritrócitos e fibras de fibrina. Conclusão: $\mathrm{O}$ trabalho contribui para uma melhoria da assistência à saúde e pode gerar um impacto positivo na prática clínica, uma vez que a facilidade de aderência de plaquetas e fibrinas à parede do cateter demonstrada neste estudo possibilita a adoção de estratégias de prevenção do trombo, tais como a interrupção de terapia por tempo prolongado, o refluxo de sangue pelo cateter, a velocidade lenta de infusão e os estados clínicos de hipercoagulopatia.

\section{DESCRITORES}

Cateteres; Cateteres Venosos Centrais; Microscopia; Fibrina; Cuidados de Enfermagem.

\section{RESUMEN}

Objetivo: Evaluar la microestructura por microscopia confocal y electrónica en trombos desarrollados en catéteres venosos centrales. Método: Investigación experimental, descriptiva en que se hizo una evaluación microestructural de trombos venosos desarrollados en catéteres venosos centrales por Microscopia Electrónica de Barrido y Microscopia Confocal de Barrido con Láser. Resultados: Fueron recolectados 78 catéteres venosos centrales en un período de tres meses. Se distinguieron distintas estructuras de fibrina: la placa de fibrina, la red de fibrina y las fibras de fibrina. Se observó que, tanto en un catéter con tres días de permanencia como en un catéter con 20 días insertado en el paciente, el trombo presentó placas de fibrina espesas adheridas a las paredes de los orificios de los catéteres. En la región central del trombo, no obstante, se observó mayor cantidad de eritrocitos y fibras de fibrina. Conclusión: El trabajo contribuyó para una mejoría de la asistencia sanitaria y puede generar un impacto positivo en la práctica clínica, toda vez que la facilidad de adherencia de plaquetas y fibrinas a la pared del catéter demostrada en este estudio posibilita la adopción de estrategias de prevención del trombo, tales como la interrupción de terapia por tiempo prolongado, el reflujo de sangre por el catéter, la velocidad lenta de infusión y los estados clínicos de hipercoagulopatía.

\section{DESCRIPTORES}

Catéteres; Catéteres Venosos Centrales; Microscopía; Fibrina; Atención de Enfermería.

\section{REFERENCES}

1. Hechler B, Gachet C. Comparison of two murine models of thrombosis induced byatherosclerotic plaque injury. ThrombHaemost. 2011;105 Suppl1:S3-12.

2. Lucas TC, Tessarolo F, Veniero P, D'Amato E, Caola I, Nollo G, et al. Quantification of fibrin in blood thrombi formed in hemodialysis central venous catheters: a pilot study on 43 CVCs. J Vasc Access. 2014;15(8):278-85.

3. Lucas TC, Tessarolo F, Jakitsch V, Caola I, Brunori G, Nollo G, et al. Blood flow in hemodialysis catheters: a numerical simulation and microscopic analysis of in vivo-formed fibrin. Artif Organs. 2014;38(7):556-65.

4. Mazur P, Sobczyński R, Ząbczyk M, Babiarczyk P, Sadowski J, Undas A. Architecture of fibrin network inside thrombotic material obtained from the right atrium and pulmonary arteries: flow and location matter. J Thromb Thrombolysis. 2013;35(1):127-9.

5. May RM, Magin CM, Mann EE, Drinker MC, Fraser JC, Siedlecki CA, et al. An engineered micropattern to reduce bacterial colonization, platelet adhesion and fibrin sheath formation for improved biocompatibility of central venous catheters. ClinTransl Med. 2015;4:9.

6. Cacciapuoti F. Some considerations about the hypercoagulable states and their treatments. Blood Coagul Fibrinolysis. 2011;22(3):155-9.

7. Bruzi LM, Mendes DC. The importance of nursing care in managing complications related to fully-implantable catheters. Rev Esc Enferm USP. 2011;45(2):510-4. DOI: http://dx.doi.org/10.1590/S0080-62342011000200031

8. Wohner N, Kovács A, Machovich R, Kolev K. Modulation of the von Willebrand factor-dependent platelet adhesion through alternative proteolytic pathways. Thromb Res. 2012;129(4):41-6.

9. Willicombe MK, Vernon K, Davenport A. Embolic complications from central venous hemodialysis catheters used with hypertonic citrate locking solution. Am J Kidney Dis. 2010;55(2):348-52.

10. Yuan H, Deng N, Zhang S, Cao Y, Wang Q, Liu X, et al. The unfolded von Willebrand factor response in bloodstream: the self-association perspective. J HematolOncol. 2012;5:65. 
11. Zhang Y, Fan S, Yao Y, Ding J, Wang Y, Zhao Z, et al. In vivo near-infrared imaging of fibrin deposition in thromboembolic stroke in mice. PLoS One. 2012;7(1):e30262.

12. Von Brühl ML, Stark K, Steinhart A, Chandraratne S, Konrad I, Lorenz M, et al. Monocytes, neutrophils, and platelets cooperate to initiate and propagate venous thrombosis in mice in vivo. J Exp Med. 2012;209(4):819-35.

13. Silvain J, Collet JP, Nagaswami C, Beygui F, Edmondson KE, Bellemain-Appaix A, et al. Composition of coronary thrombus in acute myocardial infarction. J Am CollCardiol. 2011;57(12):1359-67.

14. Brasil. Ministério da Saúde.Boletim informativo sobre a segurança do paciente e qualidade em serviços de saúde [Internet]. Brasília; 2011 [citado 2016 set]. Disponível em

15. Liebeskind DS, Sanossian N, Yong WH, Starkman S, Tsang MP, Moya AL, et al. CT and MRI early vessel signs reflect clot composition in acute stroke. Stroke. 2011;42(5):1237-43.

16. Uchida Y, Uchida Y, Sakurai T, Kanai M, Shirai S, Morita T. Characterization of coronary fibrin thrombus in patients with acute coronary syndrome using dye-staining angioscopy. ArteriosclerThrombVasc Biol. 2011;31(6):1452-60.

17. Donati G, Colì L, Cianciolo G, La Manna G, Cuna V, Montanari M, et al. Thrombosis of tunneled-cuffed hemodialysis catheters: treatment high-dose urokinase lock therapy. Artif Organs. 2012;36(1):21-8. 